\title{
Ecological Survey of Man-Biting Mosquitoes in Nnewi Metropolis South-East Nigeria
}

\author{
Onyeka Chukwudalu Ekwebene, Chukwuanugo N. Ogbuagu, Benjamin Uzonna Ononye, Angela E. Orji
}

\section{ABSTRACT}

\begin{abstract}
The survey on the ecology of man-biting mosquitoes in Nnewi was undertaken between April and June 2019. Larval stages of mosquitoes were sampled from gutters, used discarded tyres, plastic containers, water pots, clean ground water pools, plantain and banana plants axils and dirty ground water pools using ladle, sieves and bowels. Indoor biting and resting mosquitoes were collected using pyrethrum knockdown collection method (PKC) while outdoor biting mosquitoes were collected using human being volunteer as baits and collectors. Two hundred and two (202) mosquitoes comprising of four mosquito speciesnamely; Aedesaegypt $36(17.8 \%)$,

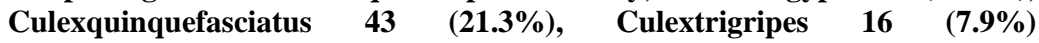
andAedesalbopictus $107(53.0 \%)$ was the highest larva to be collected. A total of sixty-eight (68) mosquitoes collected as adult made up of two speciesCulexquinquefasciatus $64(94.1 \%)$ and Anopheles gambiae 4 (5.9\%) were collected indoors. Culexquinquefasciatus $64(94.1 \%)$ constituted the highest percentage of indoor biting and resting mosquito species. One hundred and fifty-two (152) mosquitoes comprising of four species; Aedesaegypti $51(33.6 \%)$, Aedesalbopictus 96 (63.2\%), Aedesleuteocephalus $2(1.3 \%)$ and Culexquinquefasciatus $3(\mathbf{2 . 0} \%)$ were collected as outdoor biting mosquitoes. Aedesaegyptiwas the commonest outdoor biting mosquitoes in the community. One hundred and forty-three (143) mosquitoes were collected with ovitrap, Aedesalbopictus (41.9\%), Eretmapoditeschyrysogaster $2(1.4 \%)$ and Aedeaegypti $81(56,6 \%)$ been the highest collected.
\end{abstract}

Keywords: Mosquitoes, Ecology, Man-biting and Nnewi.
Published Online: September 20, 2020

ISSN: $2593-8339$

DOI: 10.24018 /ejmed.2020.2.5.461

Onyeka Chukwudalu Ekwebene *

Nnamdi Azikiwe University, Nigeria. (e-mail: chukwudaluonyeka@ ${ }^{\text {gmail.com}) ~}$

Chukwuanugo N. Ogbuagu

Nnamdi Azikiwe University Teaching

Hospital Neni, Nigeria.

Benjamin Uzonna Ononye

Nnamdi Azikiwe University, Nigeria.

Angela E. Orji

Crown Hospitals Nkpor, Nigeria.

*Corresponding Author

\section{INTRODUCTION}

Mosquitoes generally belong to the family Culicidae, the insect order known as Diptera (True flies). There are 3 subfamilies of the family Culicidaeviz: Anophelinae, Culicinae and Toxohynchitinae [1]. It is only subfamilies of Anophelinae and Culicinae that contain medically important man-biting mosquito [2], [3].

Mosquitoes are worldwide in distribution, although most species are found in the tropics and subtropics. The warmer climates in the tropical areas allow mosquitoes to be active all year round, with the ideal conditions being hot and humid with moderate rain fall. In hot climates they are able to be more active, and the rainfall gives them aquatic sites for larval and pupal stages of development [4].Mosquitoes breed in a variety of habitats where there is stagnant water bodies including swamps, ground water pools, edges of rivers, slow flowing streams, tree holes, plant axils, crab holes, broken bamboo stems, tin cans, plastic containers of all sorts, coconut shell, foot prints of animal and man, excavation ditches, stone quarry sites, discarded motor vehicle tyres, shaded quiescent water pools and cassava fermentation pots [5]-[8].
Man-biting mosquitoes are capable of transmitting diseases such as malaria, yellow fever, dengue, encephalitis and hemorrhagic fever to man [9]-[12].They also transmit animal diseases like the fowl pox of poultry, myxomatosis of rabbits, rift-valley fever of sheep, encephalitis of horses and birds and heart worm disease of dogs [13], [14]. Manbiting mosquitoes causes great harm, suffering and economic loss because of their blood sucking habits and disease transmission [15]. The number of deaths that occurs due to disease spread by mosquitoes is enormous. Over $1,000,000$ deaths have been estimated annually as a result of malaria disease which is transmitted by female anopheles mosquitoes [16]. Moreso, 30,000 deaths occur every year due to yellow fever disease transmitted by Aedesaegypti and 600 million people living in endemic areas with 200,000 estimated to be already infected [16]. The mosquito species which bite indiscriminately also play a part in transmitting zoonotic diseases from animal reservoirs to human hosts [17].

Invariably, vector control problems differ from country to country and may also vary even in different areas of the same country [18]. Therefore, there is need for separate and proper study of the breeding and biting activities of manbiting mosquitoes in various ecological zones before embarking on proper control measures. With increasing 
human population and urbanization at Nnewi due to industrialization, the main aim of this study is to investigate the ecology of man-biting mosquitoes in the community so as to determine right strategies of protecting the people from mosquito bites and mosquito-borne diseases.

\section{MATERIALS AND MethodS}

\section{A. Study Area}

Nnewi is a commercial city in Nnewi North Local Government Area, Anambra State, Nigeria. It has geographical co-ordinates of approximately latitude $6^{\circ}, 1^{1}$ North and longitude $6^{\circ}, 55^{1}$ East of Greenwich Meridian. It is made up of four villages namely:Otolo, Uruagu, Umudim and Nnewichi in the order of seniority. It is an urban area bounded in the North by Umuoji, West by Ojoto, Oba and Oraifite, East by Nnobi and Awka-Etiti and South by Amichi town, Ozu river, Ukpor and Osumenyi. Nnewi is located East of the River Niger and about $22 \mathrm{~km}$ from the commercial city of Onitsha in Anambra State [19].

Nnewi is within the tropical rain forest region of Nigeria, though it suffers from soil leaching and erosion which has reduced the soil in some areas to a porous sandy terrain. The vegetation is partly rainforest type and mosaic savanna type as a result of human activities [19].

Nnewi has an estimated population of 391,227 inhabitants according to the Nigeria census. The city spans over 1,076.9 square $\mathrm{km}$ in Anambra. Nnewi is both a commercial and industrial area as a result of the development of the local market into an international market where different commodities are sold in both retail and wholesale. Also, the large market has attracted development of different types in the community. Palm oil, Cosmetics, Motor and Motor cycle spare parts, Books, Textile, Electric cables are produced in commercial quantities in the Area. Its main trading centres include NkwoNnewi market (the largest spare parts market in West Africa), Nwafor market, Eke-Amaobi market, Eke-ochie, Eke-ichi market and OrieOtube market [19].

\section{B. Ethical Consideration}

An introductory letter was obtained from the Department of Parasitology and Entomology, Nnamdi Azikiwe University, Awka. Permission to work in the jurisdiction was obtained from igwe nnewi.The aim and objective of the research was also explained to him and also advocacy visit was paid to the heads of the four community in nnewi and their permission was also sought. Dwellers whose houses were used during the indoor spray were properly informed and their consent obtained. Volunteer staff used for collection of the outdoor man-biting adult mosquitoes and larval sampling were given adequate training on how best to collect the mosquitoes.

\section{Study Design}

The surveillance of man-biting mosquitoes was carried out in four communities in Nnewi (Umudim, Nnewichi, Otolo and Uruagu) which involved egg collection, larval and pupal collection and adult collection was done. Mosquito eggs were collected with ovitrap while immature stages (Larvae and pupae) were collected with ladle and sampled according to their breeding sites. Indoor mosquitoes were collected using pyrethrum knock-down collection method while outdoor adult mosquitoes were collected using human bait.

The locations where the ovitraps were set include around homes, cocoyam, banana/plantain and cassava plantations for collection of mosquito eggs was randomly selected. The traps were collected after 48 hours from the time it was set at the locations. Random selection type was used in sampling the habitats for larval and pupal sampling such as gutters, ground water pools, discarded tyres, containers, drums, clay pots. This was done within the period of 8:00 am-12:00 pm. Houses where mosquitoes were sampled were selected randomly. 40 houses were selected from the entire community (ten houses from each community) for PKC and this was done in early hours of the day between 6:00 am-7.30 am. Four locations were used for collection of outdoor adult mosquito using human as baits and were done between 4:30 pm-7.30 pm, where one location was selected from each community with a random type.

\section{Sampling of The Man-Biting Mosquitoes at Nnewi}

Two methods were used to determine possible mosquito breeding sites in the study area, namely: ovitrap setting and larval sampling.

\section{E. Ovitrap Setting}

Mosquitoes were collected using ovitrap setting technique as described by WHO and Onyido [9]. It is safe, economical, and environment-friendly [20]. The trap consists of a plastic cup of a litre volume, half-filled with water and lined internally with a strip of white calico cloth measuring $2 \mathrm{~cm}$ in width and a length equal to the internal perimeter of the cup [15]. The cloth serves as an oviposition substrate for the mosquitoes.

In the survey, traps were placed strategically at various locations which include under tall trees, banana plantation, close bushes and cocoa yam plantations. Ten traps were kept per location and left for two days (48 hours) before collection. At collection, the strips of white cloth were carefully removed from the containers examined for mosquito eggs and air-dried at room temperature. The eggs on the strips were counted using dissection microscope and hand lens and sent to the laboratory for hatching and rearing to adult stage for easy identification.

\section{F. Larval and Pupal Sampling}

The larval and pupal mosquito populations in this study area were obtained using larval and pupal sampling techniques [21], [22].

Collection was done between 10:00 am-12:00 noon. The samples were collected into plastic bowl using ladles then sieved into another plastic bowl to remove debris. With the aid of micropipette, the larvae were picked into specimen bottles and labelled properly. All the collections were taken to theArbo Virus Vector and Research Center laboratory where they were reared to adults and identified.

\section{G. Hatching of the Eggs}

All the egg-positive cloth paddles were air-dried for three days and soaked in white enamel basins (measuring $30 \mathrm{~cm}$ 
in diameter and $12 \mathrm{~cm}$ deep) containing water to hatch. Each basin (containing larvae) was protected from contamination with free flying mosquitoes or the escape of emerging mosquitoes with mosquito-net held tightly over the open surface with rubber bands. The clothes were removed after two days, air-dried again for three days before soaking again to ensure that all the eggs hatched out. This was repeated three times for each paddle before being discarded.

\section{H. Rearing of Larvae to Adult}

Within three days of soaking the paddles for the hatching of the eggs, tiny wrigglers were seen filling the water. They were first fed with powdered biscuits and later with Quaker oats, lightly sprinkled over the water surface. The larvae reached fourth instar in 5-7 days, and then pupated in 4-5 days with subsequent emergence of adults. The collected larval samples were also reared to the adult stage in 4-6 days before identification.

\section{Method of Collection of The Man-Biting Mosquitoes in The Study Area}

\section{i. Human Bait Collection Method}

Man-biting outdoor adult mosquitoes were collected using human baits [23], [24]. In this method of collection, human volunteers were used as baits. Collection was done between the intervals of 4:30 pm and 7:30 pm for easy attraction of the adult mosquitoes. Torchlight's, cotton wool, test tube vials, wrist watches for keeping time, pens and papers for recording the time of collections, cellophane bags for collection and collation of catches and low stools or benches were the materials that was used. All catches were recorded at quarter-hourly intervals.

On each occasion, the six human volunteers sat in twos at different locations which were about a pole apart. They rolled up the sleeves of their shirts and pair of trousers to their elbows and knees respectively to expose their extremities for mosquito bites. They put off their shoes and sandals, sat on the low stool, each team about a pole away from the other teams. With the aid of torchlight and test tube, mosquitoes alighting to bite them were collected and covered with a ball of cotton wool. The time of collections was recorded and placed in the test tube.

At the end of the collection period, the samples were sorted into quarter-hourly collection and placed in separate cellophane bags and sent to National Arbovirus and Vector Research Centre for identification.

\section{ii. Pyrethrum Knock-Down Method}

Indoor biting and resting adult mosquitoes were collected using pyrethriod-based insecticide knock-down method (PKC) [23], [24]. The adult mosquitoes were collected from rooms where at least one person slept the previous night. Collections were made in 16 houses (4 houses/Community). One room was used in each house. Before the spraying exercise, the doors and windows were shut, and white spread sheets were laid from wall to wall covering furniture and other immovable items in the room. Food items and cooking utensils were carried outside to avoid contamination. A pyrethroid-based insecticide aerosol
(Raid) was sprayed in the room and allowed to remain for 20 minutes before collection.

At the end of the 20 minutes interval, the spread sheets were folded carefully starting from the edges, taken outside the room and a pair of entomological forceps was used to pick up the knock down mosquitoes into a petri-dish that is damped. The mosquito samples collected were then conveyed to National Arbovirus and Vectors Research Centre, Enugu, for identification.

\section{J. Identification of Species of Man-Biting Mosquitoes Collected During the Study}

The mosquitoes were separated into Anopheline and Culicine groups using the length of the palps, antennae, spotted wings and speckled legs. The culicine group was separated into Aedes, Culex, Mansonia, using gross morphological features. Some of which are presence of dark and white silvery patterns on the thorax and abdomen for Aedes, and pale brown coloration without any visible ornamentation for Culex. Individual species were then identified using the keys of Service [6], Gillet [4] and Hopkins [8].

\section{K. Statistical analysis}

The biting rate of mosquitoes was computed using the formula below:

$$
\text { Bitingrate }=\frac{\text { No.of mosquitoes }}{\text { Noofbaits }} x \text { time }
$$

The result was analysed statistically using Chi-square $(\chi 2)$ test. The level of significance was set at $\mathrm{P}<0.05$.

\section{RESULTS}

\section{A. Abundance of Mosquitoes Results Obtained from Ovitrap Setting Technique}

The container breeding mosquitoes collected with ovitraps in Nnewi were 143, of which 81 (56.64\%) were Aedes aegypti, 60 (41.96\%) were Aedes albopictus and 2 (1.40\%) were Eretmapodites chrysogaster (Table 1). the mean egg per trap for the various mosquitoes varied from 0.2 eggs/traps for Eretmapodites chrysogaster and 8.1 egg/trap for Aedes aegypti. Umudim village has the highest number of eggs $95(66.43 \%)$ and the least $4(2.80 \%)$ in Nnewi-ichi village. The egg collection from other village were $34(23.78 \%)$ for Uruagu and $10(6.99 \%)$ fom Otolo village. There was no significance difference in the abudance of mosquitoes among the locations $(\mathrm{P}>0.05)$.

\section{B. Results Obtained from Larval Sampling Technique}

Two hundred and two (202) mosquitoes comprising of four species were collected in larval stage from six different grounds identified in the four communities in Nnewi (Table 2). Of the four mosquito species, Aedes albopictus 107 $(52.97 \%)$ was the most abundant while Culex tigripes 16 (7.92\%) was the least. Other mosquito species collected were Aedes aegypti 36 (17.83\%) and Culex quinquifasciatus $43(21.29 \%)$. Among the breeding site, clean ground water pools has the highest number of mosquito larva 82 
$(40.59 \%)$, while the least $5(2.48 \%)$ was from plantain and banana plant axils. The larval yield from other breeding grounds were discarded used tyres 38 (18.82\%), domestic containers comprising of clay pots, plastic drums and metal tanks $18(8.91 \%)$, dirty ground water pools $25(12.38 \%)$ and gutter $34(16.38 \%)$. Clean ground water pools and discarded used tyres were the major breeding grounds for mosquitoes at Nnewi. There was no significance difference in the number of mosquitoes collected among the different breeding tests.

TABLE 1: MOSQUITO EGGS COLLECTED WITH OVITRAP FROM THE FOUR VILLAGES

\begin{tabular}{ccccc}
\multicolumn{4}{c}{ Mosquito species identified } & \\
\cline { 2 - 4 } Villages & $\begin{array}{c}\text { Aedes } \\
\text { aegypti }\end{array}$ & $\begin{array}{c}\text { Aedes } \\
\text { albopictus }\end{array}$ & $\begin{array}{c}\text { Eretmapoditeschry- } \\
\text { sogaster }\end{array}$ & Total \\
\hline Umudim & $60(74.10 \%)$ & $35(58.3 \%)$ & $0(0.00 \%)$ & $95(66.4 \%)$ \\
Uruagu & $15(18.50 \%)$ & $18(30.0 \%)$ & $1(50.0 \%)$ & $34(23.8 \%)$ \\
Otolo & $4(4.90 \%)$ & $5(8.3 \%)$ & $1(50.0 \%)$ & $10(6.9 \%)$ \\
Nnewichi & $2(2.50 \%)$ & $2(3.3 \%)$ & $0(0.00 \%)$ & $4(2.80 \%)$ \\
Total & $81(56.64 \%)$ & $60(41.96 \%)$ & $2(1.40 \%)$ & $143(100 \%)$ \\
\hline \multicolumn{2}{c}{${ }_{2}^{2}=11.213, \mathrm{df}=6, \mathrm{P}=0.082$} & &
\end{tabular}

\section{Result Obtained from Human Bait Collection Technique}

One hundred and fifty-two (152) outdoor biting adult mosquitoes comprising of 4 specieswere gotten from the four villages in Nnewi (Table 3). Aedes albopictus 96 $(63.16 \%)$ was the common outdoor biting adult mosquito and the least were Aedesluteocephalus 2 (1.32\%). Other outdoor biting adult mosquitoes collected were Aedes aegypti 51 (33.55\%) and Culex quinquefascitus 3 (1.97\%). Aedes albopictus (1 mosquitoes/man/hour) was the commonest outdoor biting mosquito for every 1.58 number of biting mosquito in the vicinity per hour.

TABLE 3: ADULT MOSQUITOES COLLECTED THROUGHHUMAN BAIT METHOD AT NNEWI

\begin{tabular}{ccc}
\hline Mosquito species & No collected & Biting rate \\
\hline Aedes aegypti & $51(33.6 \%)$ & 0.53 \\
Aedes albopictus & $96(63 \%)$ & 1 \\
Aedes leuteocephalus & $2(1.3 \%)$ & 0.02 \\
Culex quinquefasciatus & $3(2.0 \%)$ & 0.03 \\
Total & $\mathbf{1 5 2}$ & $\mathbf{1 . 5 8}$ \\
\hline
\end{tabular}

TABLE 2: MOSQUITO SPECIES COLLECTED AS LARVAE FROM THE DIFFERENT BREEDING SITES FROM THE FOUR COMMUNITIES

\begin{tabular}{|c|c|c|c|c|c|}
\hline \multirow{2}{*}{ Breeding sites } & \multicolumn{4}{|c|}{ Mosquito species } & \multirow[t]{2}{*}{ Total } \\
\hline & A.albopictus & A. aegypti & C.quinquefasciatus & C. tigripes & \\
\hline Discarded used tyres & $34(89.5 \%)$ & $4(10.5 \%)$ & $0(0.00 \%)$ & $0(0.00 \%)$ & $38(18.8 \%)$ \\
\hline $\begin{array}{l}\text { Plastic container, clay pots, } \\
\text { drums and metal tanks }\end{array}$ & $16(88.9 \%)$ & $2(11.1 \%)$ & $0(0.00 \%)$ & $0(0.00 \%)$ & $18(8.9 \%)$ \\
\hline Clean ground pools & $52(63.4 \%)$ & $40(36.6 \%)$ & $0(0.00 \%)$ & $0(0.00 \%)$ & $82(40.6 \%)$ \\
\hline Plantain \& banana plant axils & $5(100.0 \%)$ & $0(0.00 \%)$ & $0(0.00 \%)$ & $0(0.00 \%)$ & $5(2.5 \%)$ \\
\hline Dirty ground pools & $0(0.00 \%)$ & $0(0.00 \%)$ & $15(60.0 \%)$ & $10(40.0 \%)$ & $25(12.4 \%)$ \\
\hline Gutters & $0(0.00 \%)$ & $0(0.00 \%)$ & $28(82.4 \%)$ & $6(17.7 \%)$ & $34(16.8 \%)$ \\
\hline Total & $107(53.0 \%)$ & $36(17.8 \%)$ & $43(21.3 \%)$ & $16(7.9 \%)$ & $202(100)$ \\
\hline
\end{tabular}

\section{Result Collection \\ Obtained from Pyrethrum-Knock Down}

68 adult mosquitoes was collected indoor comprised of 2 mosquito species viz: Culex quinquefasciatus and Anopheles gambiae, were collected from the 16 houses selected from the four villages in Nnewi (Table 4) of these 68 mosquitoes, 64 (94.12\%) were Culex quinquefasciatus and $4(5.88 \%)$ were Anopheles gambiae. Culex quinquefasciatus was the most abundant indoor biting adult mosquitoes in Nnewi while Anopheles gambiae was in very small quantity and was from umudimvillage only. Otolo village has the highest $27(39.71 \%)$ of indoor biting adult mosquitoes while $10(14.71 \%)$ was from umudim village having the least amount of mosquitoes. The collections from other villages were 18 (26.47\%) from nnewi-ichi village, 13 (19.12\%) from Uruagu village.

TABLE 4: QUARTER-HOURLY COLLECTIONS OF DIFFERENT OUTDOOR BITING ADULT MOSQUITOES AT NNEWI

\begin{tabular}{|c|c|c|c|c|c|}
\hline $\begin{array}{l}\text { Mosquito } \\
\text { species }\end{array}$ & $\begin{array}{c}\text { Aedes aegypti } \\
(\%)\end{array}$ & $\begin{array}{c}\text { Aedes albopictus } \\
(\%)\end{array}$ & $\begin{array}{c}\text { Aedes leuteocephalus } \\
(\%)\end{array}$ & $\begin{array}{c}\text { Culex quinquefasciatus } \\
(\%)\end{array}$ & Total \\
\hline $4: 30-4: 45 \mathrm{pm}$ & $4(7.8 \%)$ & $13(13.5 \%)$ & $0(0.0 \%)$ & $0(0.0 \%)$ & $17(11.18)$ \\
\hline $4: 45-5: 00 \mathrm{pm}$ & $0(0.0 \%)$ & $2(2.1 \%)$ & $0(0.0 \%)$ & $0(0.0 \%)$ & $2(1.32)$ \\
\hline 5:00-5: 15pm & $2(3.9 \%)$ & $1(1.0 \%)$ & $0(0.0 \%)$ & $0(0.0 \%)$ & $3(1.97)$ \\
\hline $5.15-5.30 \mathrm{pm}$ & $3(5.9 \%)$ & $0(0.0 \%)$ & $0(0.0 \%)$ & $0(0.0 \%)$ & $3(1.97)$ \\
\hline $5.30-5: 45 \mathrm{pm}$ & $3(5.9 \%)$ & $3(3.1 \%)$ & $0(0.0 \%)$ & $0(0.0 \%)$ & $6(3.95)$ \\
\hline $5.45-6: 00 \mathrm{pm}$ & $4(7.8 \%)$ & $3(3.1 \%)$ & $0(0.0 \%)$ & $0(0.0 \%)$ & $7(4.61)$ \\
\hline $6.00-6: 15 \mathrm{pm}$ & $1(2.0 \%)$ & $8(8.3 \%)$ & $0(0.0 \%)$ & $0(0.0 \%)$ & $9(5.92)$ \\
\hline $6: 15-6: 30 \mathrm{pm}$ & $14(27.5 \%)$ & $30(31.3 \%)$ & $0(0.0 \%)$ & $0(0.0 \%)$ & $44(28.95)$ \\
\hline $6: 30-6-45 \mathrm{pm}$ & $12(23.5 \%)$ & $21(21.9 \%)$ & $0(0.0 \%)$ & $0(0.0 \%)$ & $33(21.71)$ \\
\hline 6:45-7:00pm & $3(5.9 \%)$ & $2(2.1 \%)$ & $2(100.0 \%)$ & $2(66.7 \%)$ & $9(5.92)$ \\
\hline $7: 00-7: 15 \mathrm{pm}$ & $0(0.0 \%)$ & $0(0.0 \%)$ & $0(0.0 \%)$ & $1(33.3 \%)$ & $1(0.66)$ \\
\hline 7:15-7:30pm & $5(9.8 \%)$ & $13(13.5 \%)$ & $0(0.0 \%)$ & $0(0.0 \%)$ & $18(11.84)$ \\
\hline Total & $51(33.6 \%)$ & $96(63.2 \%)$ & $2(1.3 \%)$ & $3(2.0 \%)$ & $152(100)$ \\
\hline
\end{tabular}




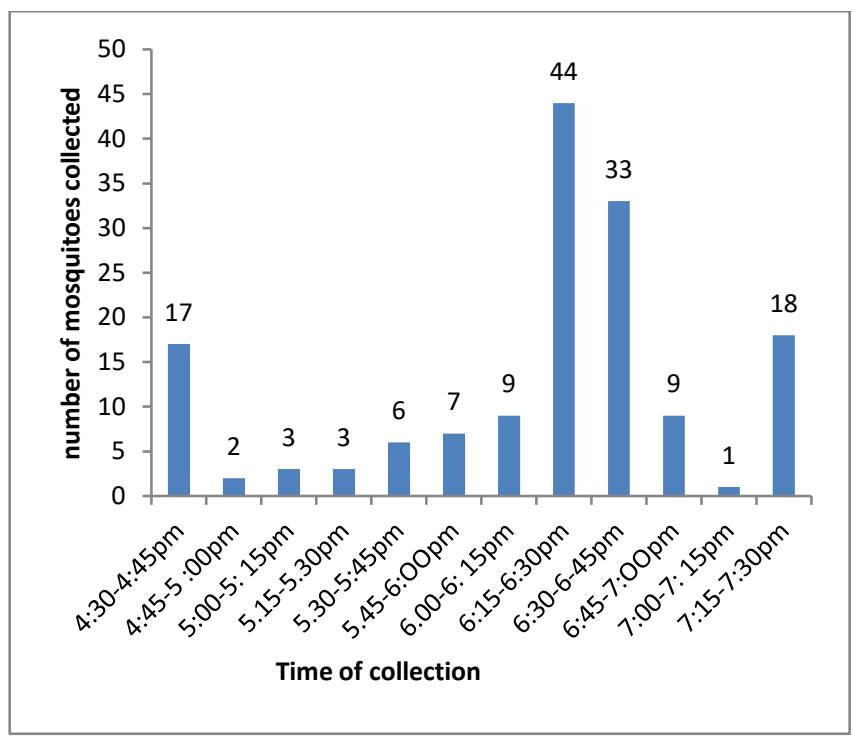

Fig. 1. Quarter-hourly collection of mosquitoes by human bait method.

TABLE 5: INDOOR BITING AND RESTING MOSQUITOES COLLECTED USING PYRETHRUM KNOCK DOWN METHOD FROM THE FOUR COMMUNITIES IN

\begin{tabular}{|c|c|c|c|c|}
\hline \multicolumn{5}{|c|}{ NNEWI } \\
\hline \multirow[b]{2}{*}{ Study village } & \multirow{2}{*}{$\begin{array}{c}\text { No of } \\
\text { houses } \\
\text { sprayed }\end{array}$} & \multicolumn{2}{|c|}{ Mosquito species } & \multirow{2}{*}{$\begin{array}{c}\text { Total no of } \\
\text { mosquito }\end{array}$} \\
\hline & & $\begin{array}{l}\text { Culexquinque- } \\
\text { fasciatus }\end{array}$ & $\begin{array}{c}\text { Anopheles- } \\
\text { gambiae }\end{array}$ & \\
\hline Nnewichi & 10 & & & \\
\hline Otolo & 10 & & & \\
\hline Uruagu & 10 & & & \\
\hline Umudim & 10 & & & \\
\hline $\begin{array}{l}\text { Nnewichi } \\
(26.47 \%)\end{array}$ & 10 & $18(100.0 \%)$ & 0 & $18(26.5 \%)$ \\
\hline Otolo $(39.71 \%)$ & 10 & $27(100.0 \%)$ & 0 & $27(39.7 \%)$ \\
\hline $\begin{array}{c}\text { Uruagu } \\
(19.12 \%)\end{array}$ & 10 & $13(100.0 \%)$ & 0 & $13(19.1 \%)$ \\
\hline $\begin{array}{l}\text { Umudim } \\
(14.71 \%)\end{array}$ & 10 & $6(60.0 \%)$ & $4(40.0 \%)$ & $10(14.7 \%)$ \\
\hline Total & 40 & $64(94.1 \%)$ & $4(5.9 \%)$ & $68(100 \%)$ \\
\hline
\end{tabular}

\section{DISCUSSION}

The surveillance of man-biting mosquitoes at Nnewi, showed variety of mosquito species in respect to their breeding sites. 202 mosquitoes was collected as larvae forms from water in gutter, used discarded tyres, water pots, drums, domestic plastic containers, clean ground water pools and dirty water pools, plantain and banana plant axils around the villages is an indication of intensive breeding of mosquitoes in the area as a result of many breeding sites in the community. The findings corroborates with the observations of Mbanugo and Okpalaononuju [25] who noted that the prepodence of mosquitoes in Awka metropolis was due to prevailing habitats in the area. Four mosquito species which include Aedes albopictus 107 (52.97\%), Aedes aegypti 36 (17.82\%), Culex quinquefasciatus $43(21.29 \%)$ and Culex tirigripes 16 $(7.92 \%)$ were collected as larvae from different breeding sites, with Aedes Albopictus 107 (52.97\%) and Culex quinquefasciatus $43(21.29 \%)$ predominating in the collections. Aedes groups were sampled from water in used dumped tyres, clay pots, plastic container, metal tanks and drums, plantain and banana plant axils, whereas Culex group where collected in dirty and clean ground water pools and gutters. Anopheles larvae were not collected during the collection of immature stages of mosquitoes and this was observed to be as a result of rainfall, since it has been implied that rainfall can affect the larval stages thereby flooding their habitats and invariably flushing out the larval stages [29]. Increased larval mortality have been observed by [26] in an unenclosed habitats in the western kenya highlands and this implied a damaging effects of rain on the larval stages. In similar study by Mbanugo and Okpalaononuju [25] in Awka metropolis, Aedes albopictus, Culex quinquefasciatus, Aedes aegypti and Culex tigripes are predominant species occuring in that area.

Only few of the traps set in the four villages were negative, high numbers were positive. However, the hatching process were very poor. Cloth paddles containing the eggs were soaked more that once before complete hatching was achieved. The large number of eggs collected within the period indicated intensive breeding of mosquitoes especially Aedes aegypti. More so, the hatching in parts can be linked to the fact that the eggs of Aedes mosquitoes are known to hatch out in small batches as an innate and adaptive strategy for surviving unfavourable condition [27].

Anopheles gambiae and Culexquinquefasciatus were the three species of mosquitoes caught indoors with Culexquinquefasciatus $64(94.12 \%)$ predominating in the collections. This is so because adults of Culexquinquefasciatus are anthropohilic, endophagic and endophilic. Culex and Anopheles mosquitoes which are usually night biters enter dwellings to bite their prey when asleep. The study of Gordon and Lavoipierre [28] observed that the more important vectors of mosquito-borne diseases are those which show a close relationship with man and prefer man to other animals as source of living.

In human bait collection method, the outdoor-biting mosquitoes collected were Aedes albopictus 96 (63.16\%), Aedesluteocephalus 2 (1.32\%), Aedes aegypti 51 (33.55\%) and Culex quinquefascitus 3 (1.97\%). Service [6] indicated that adults of Culex quinquefascitus are mainly anthropophilc, endophagic and endophilic, with Culex quinquefascitus which bites indoors but occassionally bite outdoor, the rest were Aedes mosquitoes which are diurnal and crepuscular insects [9]. Mosquito species observed in this study area are proven vectors of mosquito-borne diseases.

The present study is of public health concern because the mosquito species collected have been implicated in one type of mosquito-borne disease or the other. The people are therefore adviced to protect themselves from mosquito bites and organise control strategies which should be used to reduce mosquito-man contact vis-à-vis disease transmission among the people.

\section{CONCLUSION AND RECOMMENDATION}

This survey has provided ideas on mosquito breeding sites especially larval habitats of mosquito and the species in Nnewi. Inadequate environmental sanitation and heavy rainfall might have brought about the high mosquito 
population in the community. Mosquito species collected from the study area are vectors of one mosquito-borne diseases. The high population of Culex, Aedes and Anopheles species of mosquito in the area is a danger sign of possible epidemic, if any arbo-viral disease agents is introduced.

Health education of the populace is encouraged and suggested to control of mosquitoand to reduce man mosquito contact thereby improving the health of the people. From the result of the study represented in figures, peaks of bites were recorded at periods $6.15-6.30 \mathrm{pm}, 7.15$ $7.30 \mathrm{pm}, 4.30-4.45 \mathrm{pm}$ and $6.00-6.15 \mathrm{pm}$ and $6.45-7.00 \mathrm{pm}$ having the same number of mosquitoes. Based on this, the populace are encouraged not to fall prey to mosquito bites within these time frame. As the rate of bites recorded is sufficient enough to cause transmission of arboviral infections should any be introduced. Of utmost importance is the enlightenment of the residents of Nnewi on the environmental factors that contribute to mosquito breeding. The immediate reduction in vector population could be achieved by eliminating all possible breeding sites. The public should also be advised to use personal protective measures to avoid mosquito bites. Finally, the State Ministry of environment should continously prevent epidemic by daily surveillance and monitoring for mosquito population.

\section{COMPETING INTERESTS}

The authors declared that they have no competing interests and no funding for this research work.

\section{LIMITATIONS OF THE STUDY}

Part of the limitations to this study includes:

- There was no fund for this study because such study should be a prospective study which is capital intensive.

\section{REFERENCES}

[1] Snow, K.R. Mosquitoes.Richmond Publishing Slough. pp. 57-59, 1990.

[2] Knight, K.L. and Stone, A. A Catalog of the Mosquitoes of the World 2nd edition.Entomological Society of America, Maryland, 1977.

[3] Walker, K. and Lynch, M, "Contributions of Anopheles larval control to malaria suppression in tropical Africa: review of achievements and potential" Med. Vet. Entomol 2007, 21 (1): 2-21.

[4] Gillett, J. D.African mosquitoes and their medical importance.Willam Heinemann Medical Books Ltd London, 1972, pp 236.

[5] Onyido, A.E., Ezike, V.I., Nwankwo, E.A., and Ozumba N.A. Public health implication of giant tree in the proximity of human dwellings. Tree-hole breeding mosquitoes of the Government reservation ards (GRA) of Enugu metropolis in Southeastern Nigeria. On proceeding $3^{\text {rd }}$ National conference of the society for occupational safety and Environmental Health (SOSEH), 8-11 $1^{\text {th }}$ November 2006, Page 140143.

[6] Service, M. W. Guide to Medical Entomology. Macmillan internationalCollege edition. Macmillan Press Limited, London 1980, pp 64-226.

[7] Iwuala, M.O.E. Cassava fermentation posts as a major breeding foci for Culicine mosquitoes in Nsukka, Nigeria 1979. Nigeria Medical Journal 9:321-335.

[8] Hopkins, G.H.E. Mosquitoes of Ethiopian Regions: Bionomics of mosquitoes and taxonomy of Culicine larvae, $3^{\text {rd }}$ Edition, London 1952.

[9] Onyido, A.E., Ejike, V.I., Ozumba, N.A., Nwosu, E.G., Ikpeze, O.O., Obiukwu, M.O. and Amadi, E.S. Crepuscular man biting mosquitoes of a Tropical Zoological Garden in Enugu, South-East Nigeria. The Internet Journal of Parsitic Diseases 2009, 4(1): 1-9.

[10] Mathis, W., Hamon, J., St Cloud, A., Eyiond, M., Miller, S. Initial field studies in upper volta with dichlorvos residual fumigant as malaria eradication Technique 2. Entomological evaluation. Bull World Health Organization 1963, pp29:237-240.

[11] Gillett, J. D. (1971). Mosquitos. Richard Clay Ltd, Suffolk, pp 221.

[12] Chevillon, C, Raymond, M., Guillemaud, T., Lenormand, T. and Pasteur, N. (1999). "Population genetic of insecticide resistance in the mosquito Culexpipiens. "Biol. J. Linn. Soc., 68 (1-2): 147-57.

[13] Pates, H. and Curtis, C. (2005).Mosquito behavior and vector control.Annu Rev Entomology 50:53-70.

[14] Service, M. W. (2004) Medical Entomology for Students, 3rd edn. Cambridge University Press, Cambridge, pp 105-109.

[15] Onah, J. A. and Isiyaku S. (1996). Parasitic nematodes of some insects on JOE Plateau. Nigerian Journal of Parsitology. 17:125-127.

[16] World Health Organization (WHO) (2008). World Malaria Report 2008 http://apps.who.int/malaria/wmr2008/malaria2008.pdf (Accessed12/05/2019).

[17] Onyido, A.E., Obi, N.C., Umeanaeto, P.U., Obiukwu, M.O. and Egbuche, M.C., (2011). Malaria prevalence and indoor-biting mosquito vector abundance in Ogbunike. African Research Review, Vol. 5 1-13.

[18] Turell, M.J., O'Gunn, M.L. Dohm, D.J. and Jones, J.W. (2011). Vector competence of North American mosquitoes (Diptera: Culicidae) for West Nile vires.Journal of Medical Entomology 38:130-134.

[19] Onwutalobi, Anthony-Claret. "Nnewi Industrialization overview The Official NnewiCity Portal". www.nnewi.info. Retrieved 201509-19.

[20] Afrane, Y.A., Lawson B.W., Githeko, A.K., Yan, G. (2005). Effects of Microclimatic changes caused by land use and land cover on duration of gonotrophic cycle of Anopheles gambiae (DipteraCulicidae) in Western Kenya Highland. Journal Medical Entomology, 42:974-980.

[21] Forattini, O. P., Kakitani, I., Massad, E. and Marucci, D. (1993) Studies on mosquitoes (Diptera: Culicidae) and anthropic environment: Survey of resting adults and synanthropic behavior in South-Eastern Brazil. Revista de SaudePublica, 27,398-411.

[22] Silver, J.B. (2008) Mosquito Ecology: Field Sampling Methods, 3rd Edition. Springer, London, pp 45-48.

[23] Service, M. W. (2008). Anopheline mosquitoes (Anophelinae). MedicalEntomology for students' Fourth Edition. Pp 33-35.

[24] Okumu, F. O., Ogoma S., Biswaro L., Smallegange, R.C., Mbeyela, E., Titus E., Munk, C., Ngonyani, H., Takken, W., Mslinda, H., Mukabana, W.R., and Moore, S.J. (2010). Renia, Laurent. "Development and field Evaluation of a synthetic Mosquito Lure that is more Attractive than Human". Plos ONE5(1):875.

[25] Mbanugo J.I. and Okpalaononuju, C.N. (2003). Surveillance of mosquitoes vectors in some habitals of Awka metropolis, Anambra State Nigeria. The Nigerian Journal of parastology. Vol 24, pp 185-190.

[26] Nobuko Tuno, Wilberforce Okeka, Noboru minakawa, Mashiro takagi, Guiyun yan. Journal of medical entomology, volume 42, pages $270-277,2005$

[27] Asa Crawford Chandler, Clark P Read, Introduction To parasitology with special reference to the parasite of man, 1961.

[28] Gordon, R.M. and Lavoipierre, M.M.J. (1976). Entomology for students of medicine, fourth printing.Blackwell Scientific Publication, Oxford, pp 200.

[29] Russell, Paul F.; West, L. S.; Manwell, Reginald D. Practical Malariology. Prepared under the Auspices of the Division of Medical Sciences of the National Research Council. 1946,684 pp.

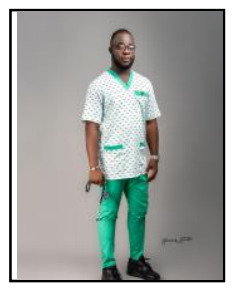

Dr Ekwebene Onyeka Chukwudalu was born in Onitsha, Anambra State, South Eastern Nigeria $\mathrm{He}$ had his primary and secondary school education in nnewi and Eziagu respectively in Anambra state and university in Nnamdi Azikiwe University Awka, where he graduated with second class upper division with a CGPA of 4.22 out of 5.00 from the department of Parasitology and Entomology in 2013. He obtained a second degree in same university and graduated in flying colours from the faculty of medicine where he obtained MB; BS (Bachalors in Medicine and Bachalors in Surgery) in 2019. Because of his passion for education he obtained a Post Graduate Diploma in Education from Nnamdi Azikiwe University, Awka in 2019. 
He is presently working as an assistant doctor in El-norah and Shekinah Glory M-Specialty Hospital Atani. He is also the founder of Sunrise Apparrel Signatures, a registered and fast growing fashion industry. He has 3 articles which are under review with peer reviewed journals.

Ekwebene Onyeka Chukwudalu is a member of Royal Society of Tropical Medicine and Hygiene. He was also a facilitator/Resource person who trained principals and head teachers in Anambra State for Covid-19 preventive measures in preparation of school reopening.

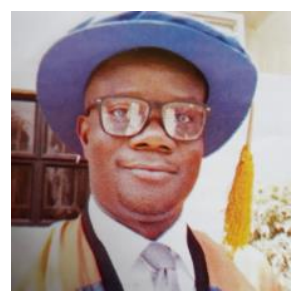

Chukwuanugo Nkemakonam Ogbuagu works in tertiary healthcare facility in the Southeast Nigeria as a Public Health Physician and Consultant Parasitologist.

He had a BSc (Hon) in Parasitology and Entomology 1998, MSc in Public Health Parasitology 2008, an MBBS (Bachelor in Medicine and Surgery) 2005, and a PhD in Public Health Parasitology 2016 from Nnamdi Azikiwe University Awka Nigeria.

Dr Chukwuanugo is a Principal Medical Officer at the Nnamdi Azikiwe University Teaching Hospital Nnewi, Nigeria. An EDCTP scholarship recipient Lisbon Portugal 2018 on Neglected Tropical Diseases (NTDs) Research. AWHO/TDR certified Implementation researcher on infectious diseases of poverty and Africa Research Excellence Fund Fellow. He is currently Secretary of Clinical and Implementation Research Network Nigeria (CIRNN) a consortium of WHO-TDR/EDCTP Senior Research Fellows.

Dr Ogbuagu attended the Alzheimer's University in London UK in 2018 and Professional Development Certificate in Leadership and Management in Health from University of Washington. A member of Nigeria Medical Association, American Society of Microbiology, etc.

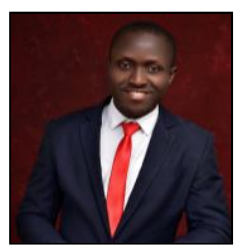

Ononye, Benjamin Uzonna was born in Jahun, Jigawa State Nigeria. He had his primary and secondary education in Oba, Anambra State and university study at Nnamdi Azikiwe University, Awka where he graduated with second-class upper division with a CGPA of 4.44 out of 5.00 from the Department of Zoology. He has his master's degree in Entomology from Nnamdi Azikiwe University, Awka. He also has a Post Graduate Diploma in Education (PGDE) certificate from National Open University, Nigeria.

He presently works as an Assistant lecturer in the Department of Zoology, Faculty of Biosciences, Nnamdi Azikiwe University, Awka. He is also the Founder/CEO UZOBEN Integrated Services Awka, Anambra State.He is also an experienced data analyst and research consultant. He has over 25 publications and abstracts in peer reviewed journals and conference presentations

Ononye Benjamin Uzonna is a reviewer and editorial board member for American Journal of Zoology.

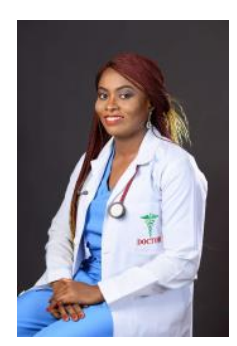

Dr Orji Angela Ezinne was born in South Eastern Nigeria, on the $21^{\text {st }}$ September,1987. After graduating with a bachelor's degree in Nursing in 2011 from Abia State University Nigeria, Dr Orji Angela, E. earned an MBBS degree from Nnamdi Azikiwe University, Nigeria in 2018.

She did her internship at Nnamdi Azikiwe University Teaching Hospital Nnewi and currently works as a MEDICAL OFFICER Crown Hospital Nkpor, Anambra State, Nigeria.She has a keen interest in research and has been involved in various research works especially in the areas of public health, maternal and child health and health care financing.

Dr Orji is Registered and Licenced to practice Medicine in the UK and is a member of the Nigerian Medical Association. 